\title{
Timed artificial insemination programs during the summer in lactating dairy cows: Comparison of the 5-d Cosynch protocol with an estrogen/progesterone-based protocol
}

\author{
M. H. C. Pereira, ${ }^{*}$ A. D. P. Rodrigues, ${ }^{*}$ T. Martins, ${ }^{*}$ W. V. C. Oliveira,† P. S. A. Silveira, $\ddagger$ M. C. Wiltbank, $\S$ \\ and J. L. M. Vasconcelost ${ }^{1}$ \\ *Aluno do Programa de Pós-Graduação em Zootecnia, Faculdade de Medicina Veterinária e Zootecnia-Universidade Estadual Paulista (UNESP), \\ Botucatu, SP 18618-000, Brazil \\ †Department of Animal Production, São Paulo State University, Botucatu 18168-000, Brazil \\ †Fazenda Santa Helena, Areado, MG 37140-000, Brazil \\ $\S$ Department of Dairy Science, University of Wisconsin, Madison 53706
}

\begin{abstract}
The objective of this study was to compare a GnRHbased to an estrogen/progesterone (E2/P4)-based protocol for estrous cycle synchronization and fixed timed artificial insemination (TAI), both designed for synchronization of ovulation and to reduce the period from follicular emergence until ovulation in cows with a synchronized follicular wave. A total of 1,190 lactating Holstein cows (primiparous: $\mathrm{n}=685$ and multiparous: $\mathrm{n}=505)$ yielding $26.5 \pm 0.30 \mathrm{~kg}$ of milk/d at $177 \pm$ $5.02 \mathrm{~d}$ in milk were randomly assigned to receive one of the following programs: $5-\mathrm{d}$ Cosynch protocol $[\mathrm{d}-8$ : controlled internal drug release $(\mathrm{CIDR})+\mathrm{GnRH}$; d -3 : CIDR removal $+\mathrm{PGF}_{2 \alpha} ; \mathrm{d}-2: \mathrm{PGF}_{2 \alpha} ; \mathrm{d} 0$ : TAI $+\mathrm{GnRH}]$ or E2/P4 protocol (d -10: CIDR + estradiol benzoate; $\mathrm{d}-3: \mathrm{PGF}_{2 \alpha} ; \mathrm{d}-2$ : CIDR removal + estradiol cypionate; d 0: TAI). Rectal temperature and circulating progesterone $(\mathrm{P} 4)$ were measured on $\mathrm{d}-3$, $-2,0$ (TAI), and 7 . The estrous cycle was considered to be synchronized when $\mathrm{P} 4$ was $\geq 1.0 \mathrm{ng} / \mathrm{mL}$ on $\mathrm{d} 7$ in cows that had luteolysis $(\mathrm{P} 4 \leq 0.4 \mathrm{ng} / \mathrm{mL}$ on $\mathrm{d} 0)$. To evaluate the effects of heat stress, cows were classified by number of heat stress events: 0, 1, and 2-or-more measurements of elevated body temperature $\left(\geq 39.1^{\circ} \mathrm{C}\right)$. Pregnancy success (pregnancy per artificial insemination, P/AI) was determined at $\mathrm{d} 32$ and 60 after TAI. The cows in the 5-d Cosynch protocol had increased circulating $\mathrm{P} 4$ at the time of $\mathrm{PGF}_{2 \alpha}$ injection $(2.66 \pm$ 0.13 vs. $1.66 \pm 0.13 \mathrm{ng} / \mathrm{mL})$. The cows in the $\mathrm{E} 2 / \mathrm{P} 4$ protocol were more likely to be detected in estrus (62.8 vs. $43.4 \%$ ) compared with the cows in the 5 -d Cosynch protocol, and expression of estrus improved $\mathrm{P} / \mathrm{AI}$ in both treatments. The cows in the 5-d Cosynch protocol had greater percentage of synchronized estrous cycle
\end{abstract}

Received October 12, 2012.

Accepted August 9, 2013.

${ }^{1}$ Corresponding author: vasconcelos@fmvz.unesp.br
(78.2\%), compared with cows in the $\mathrm{E} 2 / \mathrm{P} 4$ protocol (70.7\%). On d 60, the E2/P4 protocol tended to improve P/AI (20.7 vs. 16.7\%) and reduced pregnancy loss from 32 to $60 \mathrm{~d}$ (11.0 vs. 19.6\%), compared with the 5-d Cosynch protocol. In cows with their estrous cycle synchronized, the $\mathrm{E} 2 / \mathrm{P} 4$ protocol had greater $\mathrm{P} /$ AI (25.6 vs. $17.7 \%)$ on d 60 and lower pregnancy loss from 32 to 60 d (6.7 vs. 21.7\%) compared with cows in the 5-d Cosynch protocol. Follicle diameter affected pregnancy loss from 32 to $60 \mathrm{~d}$ only in the cows in the 5 -d Cosynch protocol, with smaller follicles resulting in greater pregnancy loss. Pregnancy per AI at d 60 was different between protocols in the cows with 2 or more measurements of heat stress ( 5 -d Cosynch $=12.2 \%$ vs. E2/P4 $=22.8 \%$ ), but not in the cows without or with 1 heat stress measurement. In conclusion, the 5-d Cosynch protocol apparently produced better estrous cycle synchronization than the $\mathrm{E} 2 / \mathrm{P} 4$ protocol but did not improve P/AI. The potential explanation for these results is that increased E2 concentrations during the periovulatory period can improve pregnancy success and pregnancy maintenance, and this effect appears to be greatest in heat-stressed cows when circulating E2 may be reduced.

Key words: 5-d Cosynch, estrogen/progesterone protocol, fertility, dairy cow

\section{INTRODUCTION}

Hormonal treatments have been developed to synchronize the time of ovulation, allowing the use of fixed timed AI (TAI) that does not require detection of estrus (Pursley et al., 1997). Currently, 2 main pharmacological approaches exist to synchronize the emergence of a new ovarian follicular wave and to induce ovulation during estrous cycle synchronization programs: (1) inducing ovulation of the dominant follicle with gonadotropins $(\mathrm{GnRH})$ at the onset of the program to synchronize the follicular wave and at the end to 
produce synchronized ovulation (e.g., Ovsynch; Pursley et al., 1995) and (2) inducing follicular atresia with a longer-acting estrogen (E2) such as estradiol benzoate $(\mathbf{E B})$ at the time of progesterone $(\mathbf{P} \mathbf{4})$ device insertion and subsequently producing synchronized ovulation at the end of the protocol by administering either EB or estradiol cypionate (ECP; Souza et al., 2009; Vasconcelos et al., 2011b; Wiltbank et al., 2011).

In Ovsynch protocols, cows that ovulate to the first GnRH injection are more likely to have a synchronized ovulation at the end of the protocol (Vasconcelos et al., 1999; Rutigliano et al., 2008), and greater pregnancy success to AI (pregnancy per AI, P/AI; Chebel et al., 2006; Rutigliano et al., 2008). The ovulatory response in lactating dairy cow receiving $\mathrm{GnRH}$ is dependent on the phase of the estrous cycle, with an average ovulation rate of $64 \%$ in lactating dairy cows at arbitrary days of the estrous cycle (Vasconcelos et al., 1999). Ovulation to the first GnRH injection may improve P/ AI not only by increasing estrous cycle synchronization, but also by reducing the period of follicle dominance in dairy cows, which might benefit P/AI (Cerri et al., 2009; Santos et al., 2010). Increasing the period of follicular dominance has been associated with reduced P/ $\mathrm{AI}$ and reduced embryo quality $7 \mathrm{~d}$ after AI (Townson et al., 2002; Bleach et al., 2004; Cerri et al., 2009). Recently, Santos et al. (2010) reported that the 5-d Cosynch protocol with TAI $72 \mathrm{~h}$ after $\mathrm{PGF}_{2 \alpha}$ injection resulted in greater P/AI compared with a 7-d Cosynch protocol, although cows in the 5-d Cosynch protocol had smaller ovulatory follicles, reduced peak circulating E2 concentrations, and a smaller proportion of cows in estrus at AI compared with cows treated with the 7-d Cosynch protocol.

The E2/P4-based protocol would also be expected to reduce the period of follicular dominance with emergence of a new follicular wave, on average $3.9 \mathrm{~d}$ after the initial EB and P4 treatment (Souza et al., 2009). These protocols have a reported efficiency of synchronizing follicular wave emergence of $84.4 \%$ (Souza et al., 2009), suggesting that follicle emergence and subsequent age of the ovulatory follicle may be well controlled with these protocols.

Numerous studies have evaluated the circulating steroid concentrations and $\mathrm{P} / \mathrm{AI}$ during estrous cycle synchronization programs for TAI. Improvements in P/ AI have been associated with elevated $\mathrm{P} 4$ concentrations at the time of the $\mathrm{PGF}_{2 \alpha}$ injection (Bisinotto et al., 2010), lower P4 concentrations near AI (Martins et al., 2011; Giordano et al., 2012; Pereira et al., 2013), increased E2 concentrations during proestrus (Cerri et al., 2004), and increased P4 concentrations after AI (Demetrio et al., 2007; Lonergan, 2011). Vasconcelos et al. (2011b) compared two 10-d estrous cycle synchro- nization protocols that used a $\mathrm{P} 4$-releasing device, one that began with $\mathrm{GnRH}$ and the other that began with $\mathrm{EB}$, with both protocols using ECP to induce ovulation at the end of the protocol. No differences on $\mathrm{P} /$ AI were observed between the 2 protocols; however, the GnRH-based protocol would be expected to have a longer period of follicular dominance due to shorter interval to emergence of the new follicular wave after GnRH compared with the EB treatment. However, previous studies have not directly compared $\mathrm{P} / \mathrm{AI}$ and hormonal concentrations during GnRH-based versus E2/P4-based programs designed to have a reduced period from follicular emergence to ovulation. In addition, it is well established that heat stress can reduce $\mathrm{P} / \mathrm{AI}$ in lactating cows (Vasconcelos et al., 2006, 2011a,b,c); however, differential effects of heat stress during distinct TAI protocols has not been previously reported.

We hypothesized that luteal regression, estrous cycle synchronization, $\mathrm{P} / \mathrm{AI}$, and pregnancy losses would be similar between these protocols in lactating dairy cows. We also hypothesized that heat stress, as measured by increases in body temperature $\geq 39.1^{\circ} \mathrm{C}$, would reduce the $\mathrm{P} / \mathrm{AI}$ in both TAI protocols. The objective of this study was to compare a GnRH-based to an E2/P4based program for estrous cycle synchronization and TAI, both designed to reduce the period from follicular emergence to ovulation

\section{MATERIALS AND METHODS}

This experiment was conducted in 5 commercial dairy farms in Minas Gerais, Brazil, starting in December 2010 and ending in March 2011. All animal procedures followed the recommendations of the Federation of Animal Science Societies (FASS, 1999). During the experimental period, cows were housed in freestall barns, with access to an adjoining sod-based paddock. Throughout the experiment, cows were milked 3 times daily. All procedures, including injections, ovarian ultrasonography, pregnancy diagnosis, blood collection, and TAI were performed while cows were restrained in self-locking head gates at the feed line. Cows were fed ad libitum a TMR diet based on corn silage, bermudagrass (Cynodon dactylon) with a corn-soybean meal-based concentrate, and minerals and vitamins, which was balanced to meet or exceed the nutritional requirements of lactating dairy cows (NRC, 2001).

\section{Animals and Treatments}

This study used a total of 1,190 lactating Holstein cows. At the beginning of the experiment $(\mathrm{d}-10)$, cows averaged $177 \pm 5.02 \mathrm{DIM}$, yielding $26.5 \pm 0.30 \mathrm{~kg}$ of milk/d, with BCS of $2.9 \pm 0.015$ [on a 1 (emaciated) 


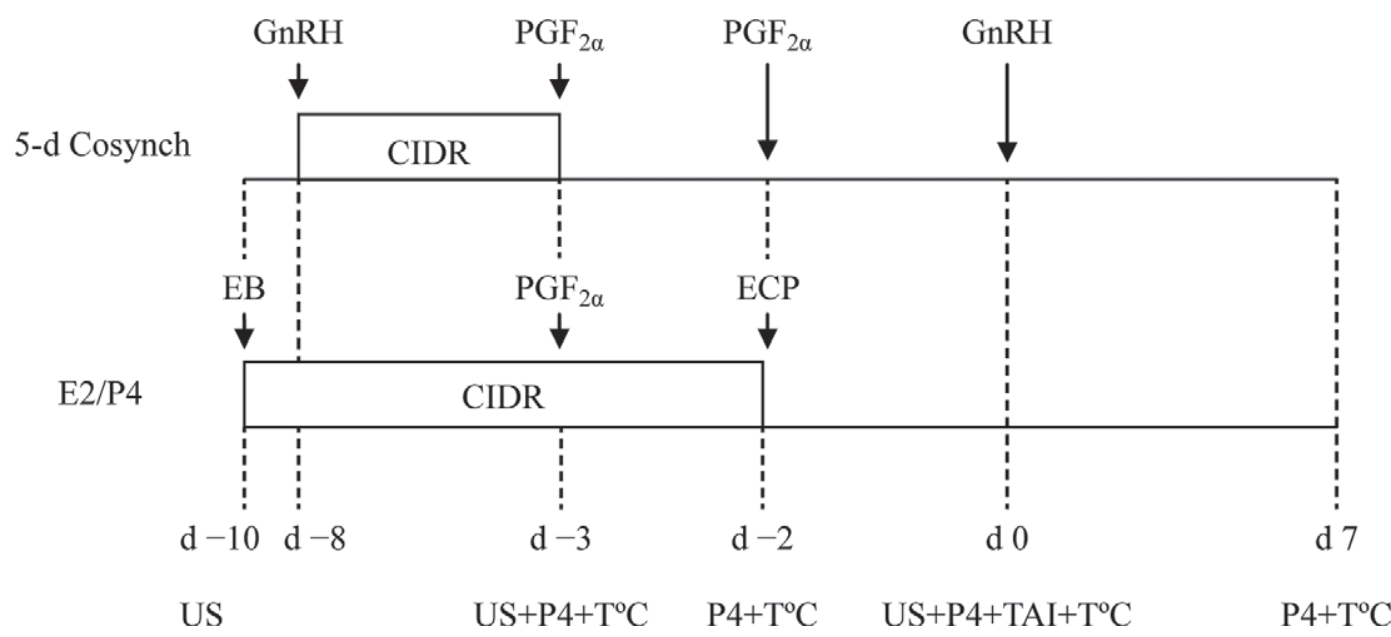

Figure 1. Experimental design. 5-d Cosynch protocol: on d -8, controlled internal drug release (CIDR) insertion and $100 \mu \mathrm{g}$ of GnRH; 5 $\mathrm{d}$ later, the CIDR was removed and cows received the first $\mathrm{PGF}_{2 \alpha}$ injection; the second $\mathrm{PGF}_{2 \alpha}$ injection was performed $24 \mathrm{~h}$ later; the GnRH and timed $\mathrm{AI}$ (TAI) were performed $48 \mathrm{~h}$ after the second $\mathrm{PGF}_{2 \alpha}$ injection. Estrogen/progesterone (E2/P4) protocol: on d -10, CIDR insertion and $2.0 \mathrm{mg}$ of estradiol benzoate $(\mathrm{EB}) ; 7 \mathrm{~d}$ later, $\mathrm{PGF}_{2 \alpha}$ injection; $24 \mathrm{~h}$ later, the CIDR was removed and cows received $1.0 \mathrm{mg}$ of estradiol cypionate (ECP); $48 \mathrm{~h}$ after CIDR removal, TAI was performed. $\mathrm{P} 4=$ blood sampling for $\mathrm{P} 4$ analysis $($ samples at $\mathrm{d}-3,-2,0$, and 7 ); US $=$ ultrasonography of the ovaries $(\mathrm{d}-10,-3$, and 0$) ; \mathrm{T}^{\circ} \mathrm{C}=$ rectal temperature $(\mathrm{d}-3,-2,0$, and 7$)$.

to 5 (obese) scale; Wildman et al., 1982], in parity 1 $(\mathrm{n}=685)$ or $\geq 2(\mathrm{n}=505)$, and having been bred 2.4 \pm 0.10 times. Within each farm, cows were blocked by parity (primiparous and multiparous) before randomization (by treatment code). All cows that were past the voluntary waiting period for the farm and not pregnant were used and randomized into the study, without regard to whether they had been previously used in the study. Within each block, cows were randomly assigned to receive 1 of 2 treatments (Figure 1): (1) The 5 -d Cosynch protocol consisted of an intravaginal progesterone device (controlled internal drug release, CIDR) containing $1.9 \mathrm{~g}$ of P4 [Pfizer Animal Health, São Paulo, Brazil; new $(\mathrm{n}=209)$ or previously used once (n $=202)$ or twice $(\mathrm{n}=186)]$ and $100 \mu \mathrm{g}$ i.m. of $\mathrm{GnRH}$ (gonadorelin; $1.0 \mathrm{~mL}$ of Fertagyl; MSD Animal Health, São Paulo, Brazil); 5 d later, the CIDR was removed and cows received $\mathrm{PGF}_{2 \alpha}$ i.m. (25 mg of dinoprost tromethamine, $5.0 \mathrm{~mL}$ of Lutalyse; Pfizer Animal Health); a second i.m. $\mathrm{PGF}_{2 \alpha}$ injection was performed $24 \mathrm{~h}$ later; the final GnRH treatment and TAI were performed 48 $\mathrm{h}$ after the second $\mathrm{PGF}_{2 \alpha}$ injection. (2) The E2/P4 protocol consisted of CIDR insertion [new $(\mathrm{n}=205)$ or previously used once $(\mathrm{n}=201)$ or twice $(\mathrm{n}=187)$ ] and $2.0 \mathrm{mg}$ i.m. of EB (2.0 mL of estrogen; Farmavet, São Paulo, Brazil) and $7 \mathrm{~d}$ later, $25 \mathrm{mg}$ of i.m. $\mathrm{PGF}_{2 \alpha}$ (5.0 $\mathrm{mL}$ of Lutalyse); $24 \mathrm{~h}$ later, the CIDR was removed and cows received $1.0 \mathrm{mg}$ i.m. of ECP $(0.5 \mathrm{~mL}$ of ECP.; Pfizer Animal Health); $48 \mathrm{~h}$ after CIDR removal, TAI was performed. All cows were inseminated in the morning of the scheduled TAI by experienced technicians $(\mathrm{n}=12)$ using commercial frozen-thawed semen from
34 different bulls. All cows were painted with chalk on their tailheads daily after the CIDR removal. Cows were considered in estrus when they were observed to stand after mounting or when chalk was completely removed.

\section{Ultrasonography}

Ovaries were examined by ultrasonography (Aloka SSD-500 with a $7.5-\mathrm{MHz}$ linear-array transducer; Hitachi Aloka Medical Ltd., Tokyo, Japan) to determine follicle diameter and the presence of a corpus luteum (CL). Cows were scanned during the TAI protocols at $\mathrm{d}-10,-3$, and 0 (Figure 1). Ovaries were drawn with the position and diameter of follicles $\geq 8 \mathrm{~mm}$ and CL. Ovulation to first GnRH injection in the 5-d Cosynch protocol was determined by the presence of a new CL at the time of $\mathrm{PGF}_{2 \alpha}$ treatment $(\mathrm{d}-3)$; those animals were classified as cows that ovulated to GnRH at CIDR insertion. Pregnancy diagnoses were performed by transrectal ultrasonography, with detection of an embryo on d 32 or a fetus on d 60 .

\section{Sample Collection}

Rectal temperature was measured in all cows using a digital thermometer (Jumbo Display Laboratory Thermometer; Delta Track, CA) in the morning, at d $-3,-2,0$, and 7 (Figure 1). Heat stress was defined as rectal temperature $\geq 39.1^{\circ} \mathrm{C}\left(<39.1^{\circ} \mathrm{C}=\right.$ no heat stress $)$, given that $39.1^{\circ} \mathrm{C}$ is considered as a threshold for heat stress in dairy cattle (Berman et al., 1985; West, 2003). 
To evaluate the effects of heat stress, cows were classified by number of heat stress events: 0,1 , and 2-or-more measurements of elevated body temperature.

Milk production was measured daily between $\mathrm{d} 0$ and 7 , and average daily production through this interval was used in the analysis. Most of the cows had blood samples collected (Figure 1) at $\mathrm{d}-3(\mathrm{n}=1,009),-2(\mathrm{n}$ $=818), 0(\mathrm{n}=842)$, and $7(\mathrm{n}=1,096)$, by coccygeal venipuncture into commercial $10-\mathrm{mL}$ blood collection tubes (Vacutainer; Becton Dickinson, Franklin Lakes, $\mathrm{NJ}$ ). After bleeding, tubes were placed on ice immediately, maintained at $4^{\circ} \mathrm{C}$ for $12 \mathrm{~h}$, and centrifuged at $1,500 \times g$ for $15 \mathrm{~min}$ at room temperature $\left(20-30^{\circ} \mathrm{C}\right)$ for serum collection. Serum was stored at $-20^{\circ} \mathrm{C}$ for subsequent P4 analysis. Serum concentrations of P4 were analyzed using the Coat-A-Count solid-phase 125I RIA kit (Siemens Healthcare Diagnostics Inc., Los Angeles, $\mathrm{CA}$ ) that had been previously validated in our laboratory (Santos and Vasconcelos, 2006). The intraassay coefficient of variation was $3.6 \%$, the interassay coefficient of variation was $10.5 \%$, and the assay sensitivity was $0.026 \mathrm{ng} / \mathrm{mL}$, calculated as 2 standard deviations below the mean counts per minute at maximum binding, as described by Pereira et al. (2013).

\section{Synchronization, Pregnancy Success, and Pregnancy Loss}

Luteolysis was defined as P4 concentration $\leq 0.4 \mathrm{ng} /$ $\mathrm{mL}$ on $\mathrm{d} 0$ (AI) as in Giordano et al. (2012). Cows with $\mathrm{P} 4$ concentration $\leq 0.4 \mathrm{ng} / \mathrm{mL}$ on $\mathrm{d} 0$ that had $\mathrm{P} 4$ concentration $\geq 1.0 \mathrm{ng} / \mathrm{mL}$ on $\mathrm{d} 7$ were considered to have had their estrous cycle synchronized. Pregnancy success $(\mathrm{P} / \mathrm{AI})$ was calculated by dividing the number of pregnant cows at $32 \mathrm{~d}$ or $60 \mathrm{~d}$ after TAI by the number of cows that received TAI. Pregnancy loss was calculated by dividing the number of cows that lost their pregnancy by the number of pregnant cows at the $32 \mathrm{~d}$ pregnancy diagnosis.

\section{Statistical Analyses}

The experiment was analyzed as a complete randomized design. The binomial variables (heat stress, estrus detection, estrous cycle synchronization, luteolysis, P/ $\mathrm{AI}$ on d 32 and d 60, and pregnancy losses from 32 to $60 \mathrm{~d})$ were analyzed using PROC GLIMMIX of SAS (SAS Institute Inc., Cary, NC), with farm as a random effect and other variables included in the models as appropriate, including effects of treatment, parity, and their interactions, as well as DIM, BCS, CIDR use, and milk yield, as covariates. The continuous dependent variables [i.e., $\mathrm{P} 4$ concentrations on day of $\mathrm{PGF}_{2 \alpha}$ treatment $(\mathrm{d}-3)$, and on $\mathrm{d}-2,0$, and 7 , and follicular diameter on d 0] were analyzed using PROC MIXED of SAS, and other variables that were included in the models were the effects of treatment, parity, and their interactions, as well as DIM, BCS, CIDR use, and milk yield, as covariables. The GLM procedure of SAS was used to determine if each individual measurement influenced P/AI. The LOGISTIC procedure was used to determine the intercept and slope(s) using maximum likelihood estimates from each significant continuousorder effect, and the probability of pregnancy was determined according to the following equation: probability $=\left(\mathrm{e}^{\text {logistic equation }}\right) /\left(1+\mathrm{e}^{\text {logistic equation }}\right)$. Logistic curves were constructed according to the minimum and maximum values detected for each individual measurement.

Satterthwaite approximation was used to determine the denominator degrees of freedom for the tests of fixed effects, with the random statement containing the effect of group. Covariables that were found to be not significant $(P>0.10)$ were removed from the statistical model. The results are expressed as least squares means \pm standard error of the mean for continuous variables. In all analyses, differences were considered significant when $P \leq 0.05$, whereas differences between $P>0.05$ and $P \leq 0.10$ were considered a statistical tendency.

\section{RESULTS}

The DIM at $\mathrm{d}-10$ for cows in the 5-d Cosynch (179 $\pm 5.86 \mathrm{~d})$ and E2/P4 $(174 \pm 5.5 \mathrm{~d})$ protocols did not differ $(P=0.58)$. The BCS at $\mathrm{d}-10$ for cows in the $5-\mathrm{d}$ Cosynch and E2/P4 protocols were similar $(P=0.30)$ and averaged $(2.92 \pm 0.02$ and $2.89 \pm 0.019)$, respectively. Milk production for cows in the 5 -d Cosynch and E2/P4 protocols were similar $(P=0.88)$ and averaged $(26.4 \pm 0.34$ and $26.5 \pm 0.35 \mathrm{~kg} / \mathrm{d})$, respectively. The previous AI number for cows in the 5-d Cosynch (2.45 $\pm 0.12)$ and E2/P4 $(2.33 \pm 0.12)$ protocols did not differ $(P=0.48)$. Mean rectal temperature at $\mathrm{d}-3,-2$, 0 , and 7 for cows in the 5 -d Cosynch and E2/P4 were similar $(P>0.10)$ and averaged $\left(39.0 \pm 0.008^{\circ} \mathrm{C}\right)$.

Table 1 shows the effect of treatments on luteolysis, estrus detection, estrous cycle synchronization, $\mathrm{P} / \mathrm{AI}$, and pregnancy loss from 32 to $60 \mathrm{~d}$. The proportion of cows that had luteolysis did not differ $(P=0.67)$ between treatments. The cows in the $\mathrm{E} 2 / \mathrm{P} 4$ protocol were more likely $(P<0.01)$ to be detected in estrus compared with the 5-d Cosynch protocol. A greater $(P=0.02)$ percentage of 5 -d Cosynch cows had their estrous cycle synchronized compared with cows in the $\mathrm{E} 2 / \mathrm{P} 4$ protocol. When all cows were included in the analysis, $\mathrm{P} / \mathrm{AI}$ on $\mathrm{d} 32$ was not $(P=0.25)$ affected by treatment, but a tendency $(P=0.07)$ existed for cows in the $\mathrm{E} 2 / \mathrm{P} 4$ protocol to have greater $\mathrm{P} / \mathrm{AI}$ on $\mathrm{d} 60$ after 
Table 1. Luteolysis, estrus detection, estrous cycle synchronization, pregnancy per AI (P/AI) at 32 and 60 $\mathrm{d}$, and pregnancy loss for lactating dairy cows receiving the 5-d Cosynch or estrogen/progesterone (E2/P4) protocols ${ }^{1}$

\begin{tabular}{|c|c|c|c|}
\hline \multirow[b]{2}{*}{ Item } & \multicolumn{2}{|c|}{ Treatment } & \multirow[b]{2}{*}{$P$-value } \\
\hline & 5-d Cosynch & $\mathrm{E} 2 / \mathrm{P} 4$ & \\
\hline Luteolysis $^{2}$ & $91.4(389 / 424)$ & $90.6(380 / 418)$ & 0.67 \\
\hline Estrus detection & $43.4(253 / 597)$ & $62.8(375 / 593)$ & $<0.01$ \\
\hline Estrous cycle synchronization ${ }^{3}$ & $78.2(287 / 389)$ & $70.7(250 / 380)$ & 0.02 \\
\hline \multicolumn{4}{|l|}{$\mathrm{P} / \mathrm{AI}$ (all cows) } \\
\hline At $32 \mathrm{~d}$ & $20.5(119 / 597)$ & $23.2(135 / 593)$ & 0.25 \\
\hline At $60 \mathrm{~d}$ & $16.7(95 / 597)$ & $20.7(119 / 593)$ & 0.07 \\
\hline Pregnancy loss & $19.6(24 / 119)$ & $11.0(16 / 135)$ & 0.05 \\
\hline \multicolumn{4}{|l|}{$\mathrm{P} / \mathrm{AI}^{3}$} \\
\hline At $32 \mathrm{~d}$ & $23.0(66 / 287)$ & $28.0(70 / 250)$ & 0.18 \\
\hline At $60 \mathrm{~d}$ & $17.7(51 / 287)$ & $25.6(64 / 250)$ & 0.03 \\
\hline Pregnancy loss & $21.7(15 / 66)$ & $6.7(6 / 70)$ & 0.01 \\
\hline
\end{tabular}

AI compared with cows in the 5-d Cosynch protocol. The percentage of cows that had pregnancy loss from 32 to $60 \mathrm{~d}$ after $\mathrm{AI}$ was lower $(P=0.05)$ in the $\mathrm{E} 2 / \mathrm{P} 4$ program compared with the 5 -d Cosynch program. In cows that had their estrous cycle synchronized, the E2/ $\mathrm{P} 4$ protocol had greater $\mathrm{P} / \mathrm{AI}(P=0.03)$ on $\mathrm{d} 60$ after $\mathrm{AI}$ and lower pregnancy loss from 32 to $60 \mathrm{~d}(P=0.01)$ compared with cows in the 5-d Cosynch protocol.

The percentage of cows with CL at $\mathrm{d}-10$ did not differ $(P=0.63)$ between the treatments [5-d Cosynch $=$ $63.5 \%(381 / 597)$ vs. $\mathrm{E} 2 / \mathrm{P} 4=62.1 \%(371 / 593)]$. On d -3 (first $\mathrm{PGF}_{2 \alpha}$ injection), a greater $(P<0.01)$ percentage of cows had CL in the 5-d Cosynch protocol $[73.6 \%$ (433/597)] compared with the E2/P4 protocol [44.3\% $(257 / 593)]$. This was probably due to ovulation of the dominant follicle to the GnRH injection for cows in the 5 -d Cosynch protocol. In both protocols, the presence of a CL on d -3 improved P/AI at $32 \mathrm{~d}$ [5-d Cosynch: no $\mathrm{CL}=13.4 \%(22 / 164)$ vs. $\mathrm{CL}=22.4 \%(97 / 433)$, $P=0.01 ; \mathrm{E} 2 / \mathrm{P} 4:$ no $\mathrm{CL}=19.4 \%(65 / 335)$ vs. $\mathrm{CL}=$ $26.9 \%(69 / 257), P=0.03]$ and $60 \mathrm{~d}$ [5-d Cosynch: no $\mathrm{CL}=12.4 \%(19 / 164)$ vs. $\mathrm{CL}=18.2 \%(76 / 433), P=$ 0.08; $\mathrm{E} 2 / \mathrm{P} 4:$ no $\mathrm{CL}=16.7 \%(56 / 335)$ vs. $\mathrm{CL}=24.1 \%$ (62/257), $P=0.02]$.

Ovulation to the first GnRH injection (at CIDR insertion) was evaluated only in the 5 -d Cosynch protocol. Cows without CL on $\mathrm{d}-10$ had greater $(P<$ 0.01) ovulation to GnRH injection at CIDR insertion [58.9\% (126/215)] compared with cows with CL [32.7\% (124/381)]. The ovulation to GnRH injection at CIDR insertion resulted in a greater $(P<0.01)$ percentage of cows that had their estrous cycle synchronized $[88.2 \%$ $(134 / 154)]$ than cows that did not ovulate to the GnRH injection at CIDR insertion [69.8\% (153/224)]. The P/ AI was greater $(P=0.01)$ at $32 \mathrm{~d}$ for cows that ovulated to the GnRH injection at CIDR insertion [24.7\%
$(62 / 250)]$ than for cows that did not ovulate $[16.5 \%$ $(57 / 346)]$, but at $60 \mathrm{~d}$, no difference $(P=0.24)$ in terms of $\mathrm{P} / \mathrm{AI}$ was detected [ovulation to $\mathrm{GnRH}$ at CIDR insertion $=18.7 \%(45 / 250)$ vs. no ovulation $=15.1 \%$ $(50 / 346)]$. A tendency existed for greater $(P=0.08)$ pregnancy loss from 32 to $60 \mathrm{~d}$ [25.7\% (17/62)] in cows that ovulated to the GnRH injection at CIDR insertion, compared with cows that did not ovulate $[12.7 \%$ $(7 / 57)]$.

Table 2 shows the $\mathrm{P} 4$ concentrations during the protocol, at $\mathrm{d}-3,-2,0$, and 7 . Concentrations of $\mathrm{P} 4$ were greater $(P<0.01)$ for 5 -d Cosynch at $\mathrm{d}-3$ compared with the E2/P4 protocol. At d $-2, \mathrm{P} 4$ concentration was lower $(P<0.01)$ for the 5 -d Cosynch compared with the E2/P4 protocol. Circulating P4 concentrations did not differ $(P=0.20)$ between treatments at d 0 . At d 7, P4 concentrations were greater $(P<0.01)$ for the 5-d Cosynch protocol compared with the E2/P4 protocol when all cows were included in the analysis. When only cows that had their estrous cycle synchronized were included in the analysis, no difference $(P=$ 0.83) was observed in $\mathrm{P} 4$ concentration on $\mathrm{d} 7$.

The follicle diameter at AI $(\mathrm{d} 0)$ had an effect $(P=$ 0.05 ) on estrous cycle synchronization in both treatments, with bigger follicles resulting in improved estrous cycle synchronization (Figure 2). The data for $\mathrm{P} / \mathrm{AI}$ by follicle diameter were evaluated only in cows that had their estrous cycle synchronized. In the 5-d Cosynch protocol, the follicle diameter had a linear effect on $\mathrm{P} / \mathrm{AI}$ at $\mathrm{d} 32(P=0.05)$ and $60(P<0.01)$. In the $\mathrm{E} 2 / \mathrm{P} 4$ program, the $\mathrm{P} / \mathrm{AI}$ at $\mathrm{d} 32(P=0.01)$ and $60(P=0.02)$ was affected by the follicle diameter at AI (d 0), with smaller and larger follicles resulting in decreased $\mathrm{P} / \mathrm{AI}$ (Figure $3 \mathrm{~A}$ and $\mathrm{B}$ ). The follicle diameter affected pregnancy loss from 32 to $60 \mathrm{~d}(P=$ 0.04) in the 5-d Cosynch protocol, with smaller follicles 
Table 2. Progesterone concentration at $\mathrm{PGF}_{2 \alpha}$ injection $(\mathrm{d}-3), 1 \mathrm{~d}$ after $\mathrm{PGF}_{2 \alpha}$ injection $(\mathrm{d}-2)$, at timed AI (TAI), and $7 \mathrm{~d}$ after TAI (d 7) for lactating dairy cows receiving the 5-d Cosynch or estrogen/progesterone $(\mathrm{E} 2 / \mathrm{P} 4)$ protocols $^{1}$

\begin{tabular}{|c|c|c|c|}
\hline \multirow[b]{2}{*}{ Progesterone (ng/mL) } & \multicolumn{2}{|c|}{ Treatment } & \multirow[b]{2}{*}{$P$-value } \\
\hline & 5-d Cosynch & $\mathrm{E} 2 / \mathrm{P} 4$ & \\
\hline At $\mathrm{PGF}_{2 \alpha}$ injection $(\mathrm{d}-3)$ & $2.66 \pm 0.13(499)$ & $1.66 \pm 0.13(511)$ & $<0.01$ \\
\hline $1 \mathrm{~d}$ after $\mathrm{PGF}_{2 \alpha}$ injection $(\mathrm{d}-2)^{2}$ & $0.47 \pm 0.05(400)$ & $0.78 \pm 0.04(418)$ & $<0.01$ \\
\hline At AI (d 0) & $0.18 \pm 0.03(424)$ & $0.21 \pm 0.03(418)$ & 0.20 \\
\hline $7 \mathrm{~d}$ after AI (d 7) & $1.75 \pm 0.11(549)$ & $1.52 \pm 0.11(547)$ & $<0.01$ \\
\hline $7 \mathrm{~d}$ after $\mathrm{AI}(\mathrm{d} 7)^{3}$ & $2.07 \pm 0.08(287)$ & $2.05 \pm 0.08(250)$ & 0.83 \\
\hline
\end{tabular}

${ }^{1}$ Results are presented as LSM \pm SEM (no.).

${ }^{2}$ Five-day Cosynch: at second $\mathrm{PGF}_{2 \alpha}$ injection; E2/P4: at controlled internal drug release (CIDR) removal.

${ }^{3}$ Cows that had luteolysis and their estrous cycle synchronized ( $\mathrm{P} 4$ concentration $\geq 1.0 \mathrm{ng} / \mathrm{mL}$ at $\mathrm{d} 7$ ).

resulting in greater pregnancy loss from 32 to $60 \mathrm{~d}$, but, no effect $(P=0.32)$ of follicle diameter on pregnancy loss from 32 to $60 \mathrm{~d}$ was observed in the $\mathrm{E} 2 / \mathrm{P} 4$ protocol (Figure 4).

Expression of estrus improved $(P<0.01)$ the percentage of cows that had their estrous cycle synchronized [no estrus $=63.8 \%(220 / 357)$; estrus $=83.4 \%$ $(317 / 387)]$, independent of treatment $(P=0.20)$. Expression of estrus was associated with increased $(P<$ $0.01) \mathrm{P} / \mathrm{AI}$ at $32 \mathrm{~d}$ [no estrus $=16.2 \%(89 / 562)$; estrus $=26.5 \%(165 / 628)]$ and $\mathrm{d}-60$ pregnancy diagnosis [no estrus $=13.3 \%(71 / 562) ;$ estrus $=23.1 \%(143 / 628)$; $P<0.01$ ], independent of treatment (d 32: $P=0.47$; d 60: $P=0.42)$. A tendency $(P=0.10)$ existed for greater pregnancy loss from d 32 to 60 in cows that did not show estrus [no estrus $=19.7 \%(18 / 89)$; estrus $=$ $12.4 \%(22 / 165)]$, independent of treatment $(P=0.96)$. In cows that had their estrous cycle synchronized, expression of estrus was associated with an increase $(P=$

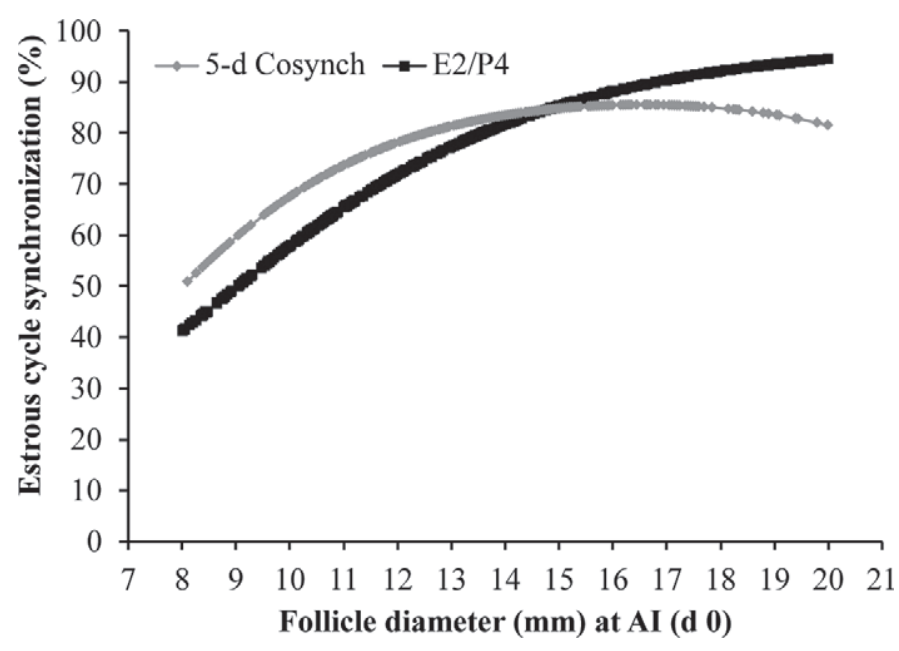

Figure 2. Effect of follicle diameter at AI (d 0) on percentage of estrous cycle synchronization [progesterone $(\mathrm{P} 4)$ concentration $\geq 1.0$ $\mathrm{ng} / \mathrm{mL}$ at $\mathrm{d} 7]$ in cows that had luteolysis ( $\mathrm{P} 4$ concentration $\leq 0.4 \mathrm{ng} /$ $\mathrm{mL}$ at $\mathrm{d}$ 0) receiving estrogen/P4 (E2/P4) or 5-d Cosynch protocols. Five-day Cosynch $(P=0.05): \mathrm{y}=-0.0244 \mathrm{x}^{2}+0.8074 \mathrm{x}-4.8988 ; \mathrm{E} 2 /$ $\mathrm{P} 4(P=0.05): \mathrm{y}=-0.00704 \mathrm{x}^{2}+0.4642 \mathrm{x}-3.6196$.
$0.05)$ in $\mathrm{P} / \mathrm{AI}$ at $\mathrm{d}-32$ [no estrus $=20.9 \%(46 / 220)$; estrus $=28.4 \%(90 / 317)]$ and d-60 $(P=0.05)$ pregnancy diagnosis $[$ no estrus $=17.3 \%(38 / 220)$; estrus $=24.3 \%$ $(77 / 317)]$, independent of treatment $(d 32: P=0.34$; d 60: $P=0.31)$. No difference $(P=0.61)$ was observed for pregnancy loss from d 32 to 60 for cows detected or not in estrus [estrus $=13.2 \%(13 / 90)$; no estrus $=$ $16.5 \%(8 / 46)]$, independent of treatment $(P=0.58)$.

Heat stress was clearly present in our experiment, with $50.2 \%(597 / 1,190)$ of cows having 2 or more measurements of elevated body temperature $\left(\geq 39.1^{\circ} \mathrm{C}\right)$ and $73.7 \%(877 / 1,190)$ with 1 or more measurements of elevated body temperature during the experiment. Cows with temperature $>39.1^{\circ} \mathrm{C}$ had lower $\mathrm{P} / \mathrm{AI}$ at $\mathrm{d} 60$ compared with cows with temperature $<39.1^{\circ} \mathrm{C}$ at $\mathrm{d}-3$ $\left[\geq 39.1^{\circ} \mathrm{C}=12.7 \%(57 / 462) ;<39.1^{\circ} \mathrm{C}=22 \%(157 / 727)\right.$; $P<0.01]$, at $\mathrm{d}-2\left[\geq 39.1^{\circ} \mathrm{C}=11.6 \%(55 / 480) ;<39.1^{\circ} \mathrm{C}\right.$ $=22.9 \%(159 / 709) ; P<0.01]$ at $\mathrm{d} 0\left[\geq 39.1^{\circ} \mathrm{C}=15 \%\right.$ $\left.(67 / 476) ;<39.1^{\circ} \mathrm{C}=20.9 \%(147 / 714) ; P<0.01\right]$ and at $\mathrm{d} 7\left[\geq 39.1^{\circ} \mathrm{C}=12.8 \%(67 / 537) ;<39.1^{\circ} \mathrm{C}=22.8 \%\right.$ $(147 / 653) ; P<0.01]$. Cows with 2 or more measurements of elevated body temperature had a reduction in $\mathrm{P} / \mathrm{AI}$ at $\mathrm{d}-32$ and -60 pregnancy diagnoses (Table $3)$. Although an effect was observed of treatment on percentage of cows that had their estrous cycle synchronized, this effect of treatment was independent of heat stress and heat stress had no effect on the percentage of cows that had their estrous cycle synchronized to either the $\mathrm{GnRH}(P=0.88)$ or $\mathrm{E} 2 / \mathrm{P} 4(P=0.55)$ protocols. Table 3 shows the treatment effects on $\mathrm{P} /$ AI and pregnancy loss from d 32 to 60 in cows with different numbers of heat stress measurements during the protocols. At the d-32 pregnancy diagnosis, no effect of treatment was observed (5-d Cosynch vs. E2/ $\mathrm{P} 4)$ in cows that did not have any measurements of an elevated temperature or in cows with 1 measurement of an elevated temperature. However, a tendency $(P$ $=0.09$ ) for effect of treatment was observed on $\mathrm{P} / \mathrm{AI}$ in cows that had 2 or more periods of elevated body temperature. Similarly, P/AI at the d-60 pregnancy di- 

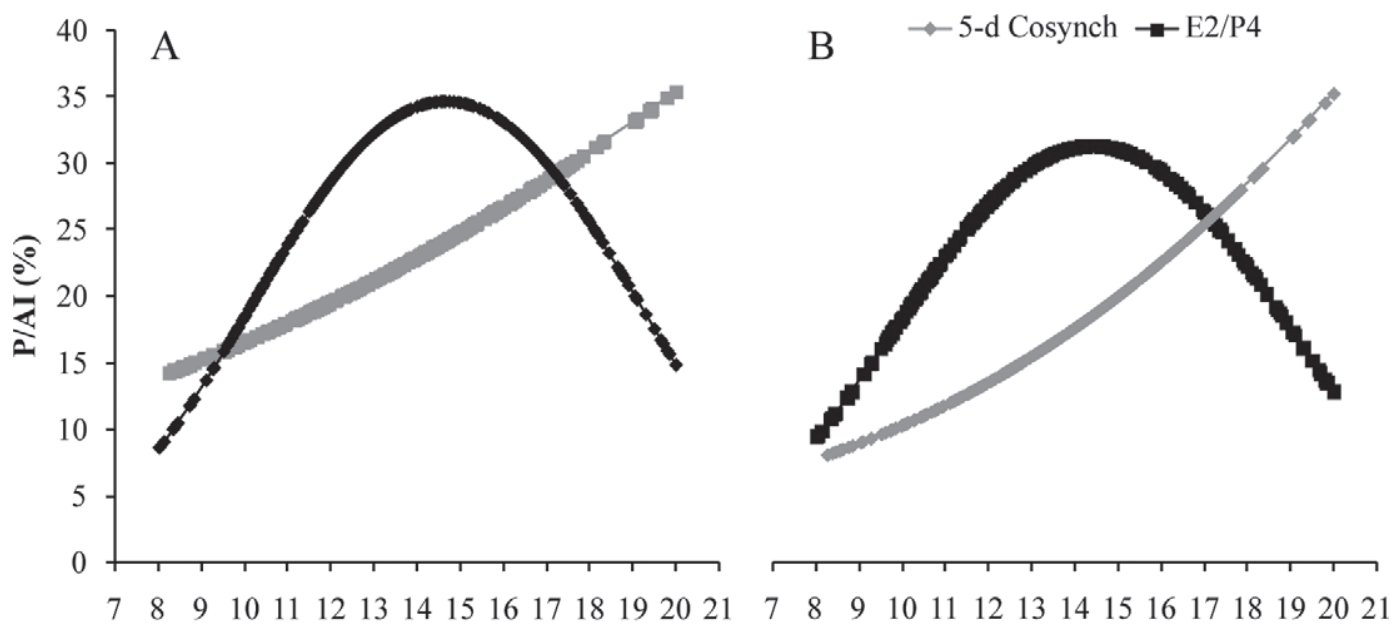

Follicle diameter (mm) at AI (d 0)

Figure 3. Effect of follicle diameter at AI (d 0) on pregnancy per AI (P/AI) at $32 \mathrm{~d}$ (panel A) and $60 \mathrm{~d}$ (panel B) in cows that had their estrous cycle synchronized [progesterone (P4) concentration $\leq 0.4 \mathrm{ng} / \mathrm{mL}$ at d 0 and $\mathrm{P} 4$ concentration $\geq 1.0 \mathrm{ng} / \mathrm{mL}$ at d 7], receiving estrogen/ P4 (E2/P4) or 5-d Cosynch protocols. At $32 \mathrm{~d}, 5$-d Cosynch $(P=0.05): \mathrm{y}=0.1049 \mathrm{x}-2.6482 ; \mathrm{E} 2 / \mathrm{P} 4(P=0.01): \mathrm{y}=-0.0361 \mathrm{x}^{2}+1.0604 \mathrm{x}-$ 8.3885. At $60 \mathrm{~d}$, 5-d Cosynch $(P<0.01): \mathrm{y}=0.1566 \mathrm{x}-3.7237 ; \mathrm{E} 2 / \mathrm{P} 4(P=0.02): \mathrm{y}=-0.0332 \mathrm{x}^{2}+0.9607 \mathrm{x}-7.7010$.

agnosis was different $(P=0.01)$ between protocols only in cows with 2 or more measurements of heat stress and not in cows without heat stress or with only 1 heat stress measurement. Finally, pregnancy loss from d 32 to 60 was not altered by heat stress; however, the differential effects of the protocols on pregnancy loss from d 32 to 60 was only significant $(P=0.03)$ in cows with 2 or more measurements of elevated temperature.

\section{DISCUSSION}

This study compared the pregnancy success to AI following synchronized ovulation using 2 protocols that have been developed to have a reduced period between follicular wave emergence and ovulation. The Ovsynchtype protocols use GnRH to synchronize the follicular wave by ovulation of a dominant follicle at the start of the protocol, and to synchronize ovulation at the end of the protocol, allowing TAI. In contrast, E2/P4-based protocols start using E2 products in the presence of $\mathrm{P} 4$ (in our study, $2.0 \mathrm{mg}$ of $\mathrm{EB}$ ) to induce atresia of the follicle and synchronize emergence of a new follicular wave. At the end of the E2/P4-based protocol, another E2 treatment (in our study, $1.0 \mathrm{mg}$ of ECP) in the absence of $\mathrm{P} 4$ is used to synchronize ovulation and al-

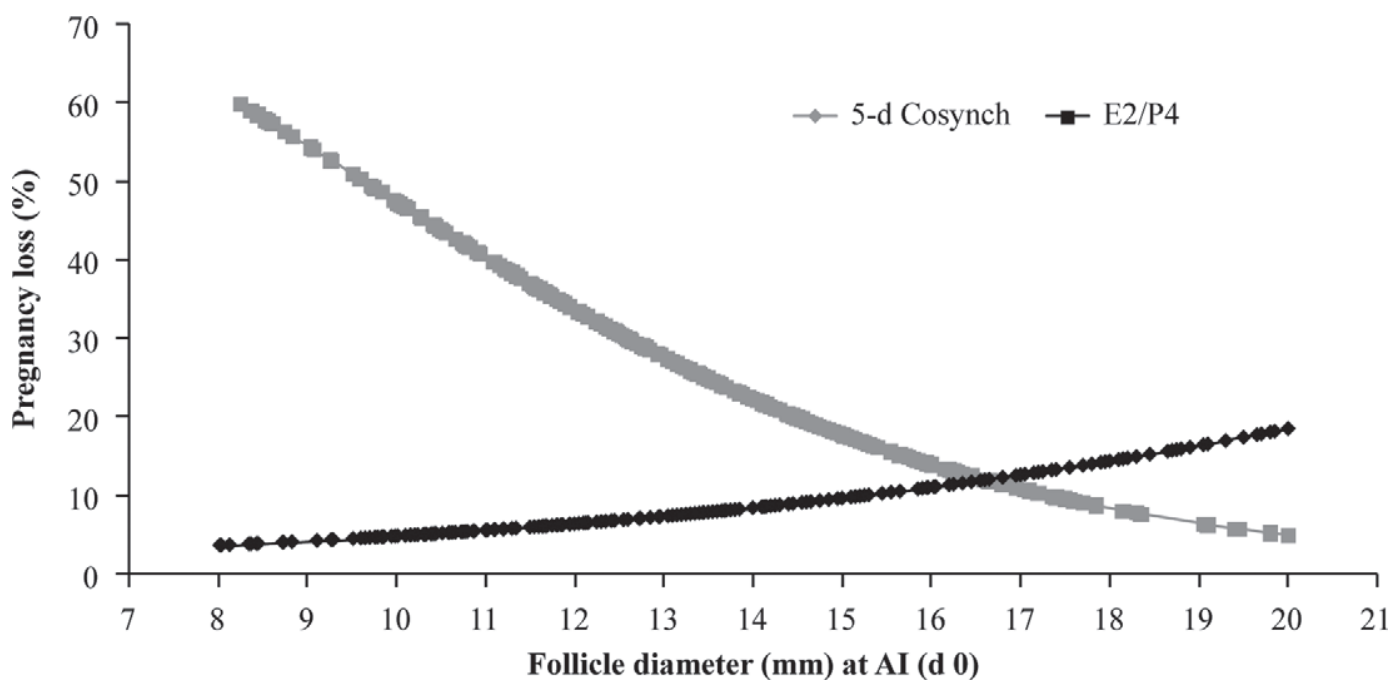

Figure 4. Effect of follicle diameter at AI on pregnancy loss between 32 and $60 \mathrm{~d}$ in cows that had their estrous cycle synchronized [progesterone (P4) concentration $\leq 0.4 \mathrm{ng} / \mathrm{mL}$ at d 0 and $\mathrm{P} 4$ concentration $\geq 1.0 \mathrm{ng} / \mathrm{mL}$ at d 7$]$, receiving estrogen/P4 (E2/P4) or 5-d Cosynch protocols. Five-day Cosynch $(P=0.04): \mathrm{y}=-0.276 \mathrm{x}+2.4648 ; \mathrm{E} 2 / \mathrm{P} 4(P=0.32): \mathrm{y}=0.01063 \mathrm{x}-3.8241$. 
Table 3. Estrous cycle synchronization, pregnancy per AI (P/AI) at 32 and $60 \mathrm{~d}$, and pregnancy loss in lactating dairy cows receiving the 5-d Cosynch or estrogen/progesterone (E2/P4) protocols compared with occurrence of heat stress $\left(\geq 39.1^{\circ} \mathrm{C}\right)^{1}$

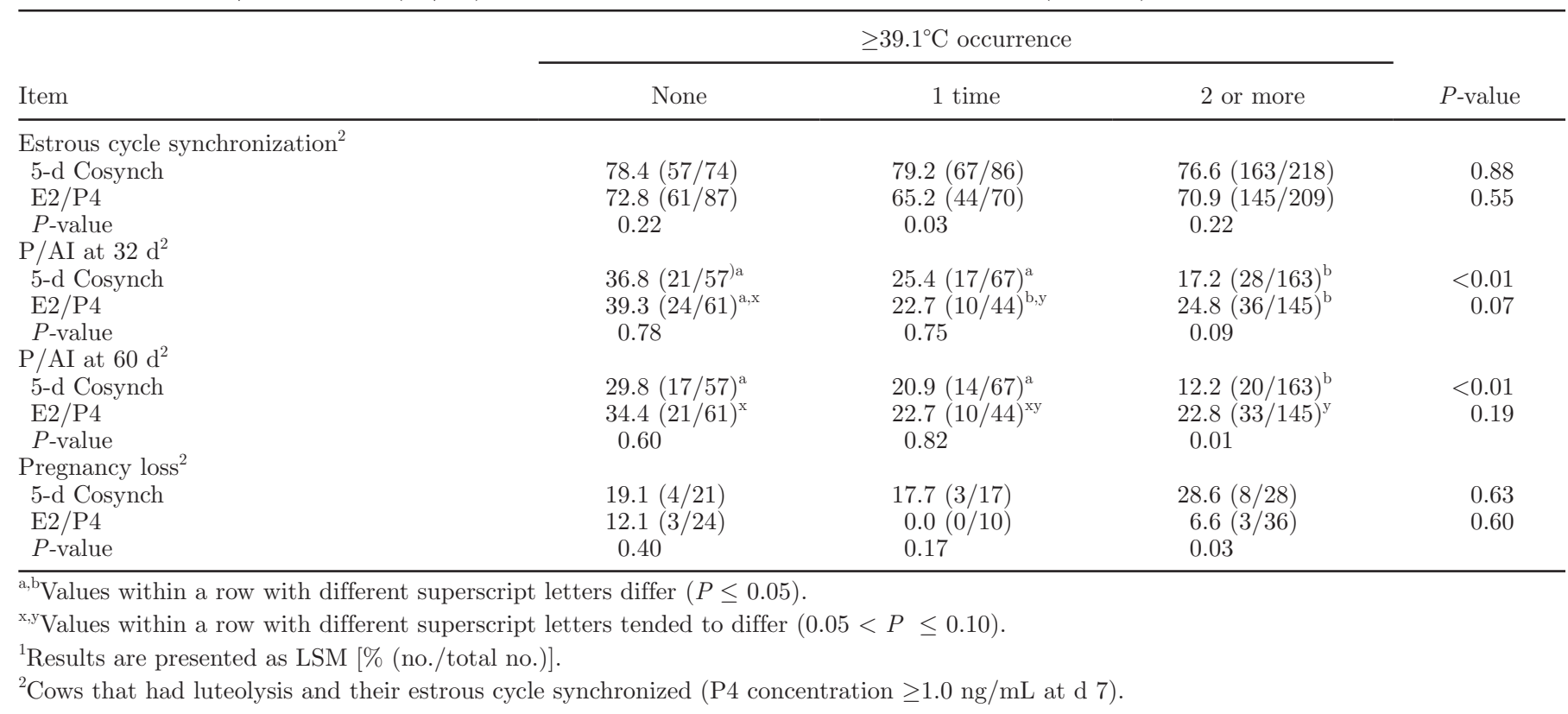

low TAI. A previous study that compared GnRH-based with E2-based protocols found no difference between the protocols (Vasconcelos et al., 2011b); however, ECP was used to synchronize ovulation at the end of both the GnRH-based and E2-based protocols, whereas in our study, we used GnRH at the beginning and end of the Ovsynch protocol. In addition, we attempted to have similar ages of the ovulatory follicle in synchronized cows by using a shortened GnRH protocol (the 5-d Cosynch protocol), which has been extensively evaluated in beef (Bridges et al., 2008) and dairy cows (Bisinotto et al., 2010; Santos et al., 2010; Ribeiro et al., 2012). We expected similar P/AI with these 2 protocols, and we expected the physiological measurements to improve our understanding of potentially divergent reasons for $\mathrm{P} / \mathrm{AI}$ with the 2 protocols. Contrary to our expectations, $\mathrm{P} / \mathrm{AI}$ increased with the $\mathrm{E} 2 / \mathrm{P} 4$ protocol compared with the 5-d Cosynch protocol. This was clearly demonstrated at the d-60 pregnancy diagnosis in cows that had their estrous cycle synchronized, with $\mathrm{P} / \mathrm{AI}$ being 7.9 percentage points higher in the E2/P4 protocol than in the 5 -d Cosynch (Table 1), which produced a substantial relative improvement with $44.6 \%$ more pregnancies $(7.9 / 17.7)$ using the $\mathrm{E} 2 / \mathrm{P} 4$ protocol. A primary reason for the reduced $\mathrm{P} / \mathrm{AI}$ in the 5 - $\mathrm{d}$ Cosynch protocol was the high pregnancy loss in this group, with more than twice as many pregnancy losses between d 32 and 60 of pregnancy compared with the E2/P4 protocol. Collection and analysis of circulating $\mathrm{P} 4$ concentrations in almost all cows $\left(85 \%\right.$ at $\mathrm{PGF}_{2 \alpha}$ injection; $69 \% 1 \mathrm{~d}$ after $\mathrm{PGF}_{2 \alpha}$ injection; $71 \%$ at TAI;
$92 \% 7 \mathrm{~d}$ after $\mathrm{AI}$ ) and follicle diameter at AI (d 0) in all cows $(\mathrm{n}=1,090)$ allowed evaluation of potential mechanisms that may have produced this difference in $\mathrm{P} / \mathrm{AI}$.

Although the $\mathrm{P} / \mathrm{AI}$ was lower in the 5-d Cosynch protocol, most physiological measures indicated that this protocol produced better estrous cycle synchronization. For example, it was anticipated that cows in the 5 -d Cosynch protocol would have increased circulating $\mathrm{P} 4$ at the time of the $\mathrm{PGF}_{2 \alpha}$ treatment. As expected, treatment with GnRH substantially increased circulating $\mathrm{P} 4$ at the time of $\mathrm{PGF}_{2 \alpha}$ treatment (Table 2), probably due to ovulation of a dominant follicle to the GnRH injection at CIDR insertion. Thus, the 5-d Cosynch protocol had more cows with a CL at the time of $\mathrm{PGF}_{2 \alpha}$ injection than found in the E2/P4 protocol. The presence of a $\mathrm{CL}$ at the time of $\mathrm{PGF}_{2 \alpha}$ injection was also associated with improved $\mathrm{P} / \mathrm{AI}$ in either protocol. This is similar to results that have been previously reported during Ovsynch protocols (Vasconcelos et al., 1999) or during the 5-d Cosynch protocol (Bisinotto et al., 2010). Thus, although the 5-d Cosynch protocol increased the percentage of cows with a CL at the time of $\mathrm{PGF}_{2 \alpha}$ injection and increased $\mathrm{P} 4$ concentration during follicle growth, both factors that have been associated with improved $\mathrm{P} / \mathrm{AI}$, some aspect of the $\mathrm{E} 2 / \mathrm{P} 4$ protocol appeared to reduce the negative effect of low $\mathrm{P} 4$ concentration during follicle growth, because cows without a $\mathrm{CL}$ at $\mathrm{PGF}_{2 \alpha}$ injection in the $\mathrm{E} 2 / \mathrm{P} 4$ protocol had P/AI at d 60 similar (16.7\%) to cows with a CL at $\mathrm{PGF}_{2 \alpha}$ injection in the 5-d Cosynch protocol (18.2\%). 
Another obvious difference between the 2 protocols is that beginning the $\mathrm{E} 2 / \mathrm{P} 4$ protocol with $\mathrm{EB}$ probably synchronized the follicular wave in a greater percentage of cows than beginning with $\mathrm{GnRH}$ treatment in the 5-d Cosynch protocol. For example, GnRH at the beginning of an Ovsynch-TAI protocol resulted in ovulation in $64 \%$ of cows in a previous study (Vasconcelos et al., 1999). However, only $42 \%$ ovulation to $\mathrm{GnRH}$ injection at CIDR insertion was observed in the 5-d Cosynch protocol in the present study, possibly related to heat stress. Although we did not evaluate complete follicular dynamics in all cows in this study, a previous study reported synchronized follicular wave emergence with EB in $84.4 \%$ of cows (Souza et al., 2009). Thus, it is possible that the $\mathrm{E} 2 / \mathrm{P} 4$ protocol produced better control of follicle emergence and diameter, compared with the GnRH-based protocol. This may result in better control of follicular age and possibly embryo quality (Cerri et al., 2009).

Another interesting difference was that the cows treated with the 5-d Cosynch protocol had a greater percentage of cows that had their estrous cycle synchronized (78.2 vs. $70.7 \%$ ), resulting in greater $\mathrm{P} 4$ concentrations at $7 \mathrm{~d}$ after TAI than in cows treated with the E2/P4 protocol. This result might be expected because GnRH directly induces an LH surge to produce ovulation, whereas ECP shows a delayed and slow increase in circulating E2 concentration (Souza et al., 2005), which requires a proper response of both the hypothalamus, pituitary, and dominant follicle to produce ovulation. However, it is clear in Figure 2 that the 5-d Cosynch protocol only improved estrous cycle synchronization in small follicles. Overall, the percentage of cows that had their estrous cycle synchronized in this study seemed to be lower than previous reports for the 5-d Cosynch [84.3\% (43/51)] (Santos et al., 2010) or the E2-CIDRECP $[84 \%(21 / 25)$ to $87.5 \%(21 / 24)]$ (Souza et al., 2009 ) protocols. In contrast to a previous study (LópezGatius et al., 2005) we did not observe evidence for an effect of heat stress on estrous cycle synchronization to either the GnRH or E2/P4 protocols, as estrous cycle synchronization was not altered in cows with increasing numbers of elevated body temperature measurements (Table 3).

The E2/P4 protocol improved the expression of estrus, which was associated with an increase in $\mathrm{P} / \mathrm{AI}$ in cows that had their estrous cycle synchronized, in both TAI protocols at the d-32 and -60 pregnancy diagnoses. These results are similar to those of previous studies performed in dairy cows with various TAI protocols. In Heatsynch protocols, cows that displayed estrus after the ECP had greater P/AI [42.5\% (306)] than cows not in estrus $[21.1 \%(71)]$ at TAI (Cerri et al., 2004). In a separate study using the Heatsynch protocol, detection of estrus improved the $\mathrm{P} / \mathrm{AI}$ at $\mathrm{d} 27$ (43.6 vs. $17.0 \% ; P<$ $0.001)$ and $\mathrm{d} 41$ (36.6 vs. $12.0 \% ; P<0.001)$, compared with cows not detected in estrus (Galvão et al., 2004). Cows displaying estrus in protocols with Cosynch at 48 or $72 \mathrm{~h}$ after the $\mathrm{PGF}_{2 \alpha}$ treatment had greater $\mathrm{P} / \mathrm{AI}$ at $40 \mathrm{~d}(54.7$ vs. $31.5 \%)$ and $68 \mathrm{~d}(53.3$ vs. $31.5 \%)$ after AI (Hillegass et al., 2008).

Follicle diameter has been associated with $\mathrm{P} / \mathrm{AI}$ in several studies. For example, ovulation of too small of a follicle is associated with reduced $\mathrm{P} / \mathrm{AI}$, reduced E2 concentration, an increase in the incidence of short luteal phases (Vasconcelos et al., 2001), and sometimes increased pregnancy loss (Perry et al., 2005). Ovulation of too large of a follicle can also be associated with reduced P/AI, possibly because of excessive length of dominant follicle persistence (Townson et al., 2002; Bleach et al., 2004; Cerri et al., 2009). One limitation of our study was that ovulation was determined by elevated circulating $\mathrm{P} 4$ concentration on $\mathrm{d} 7$ and not by direct ultrasound evaluation of the ovaries. Therefore, some follicles that were observed by ultrasound on $\mathrm{d} 0$ may not have been the ovulatory follicle. Nevertheless, similar to previous studies, we observed that follicle size had an effect on $\mathrm{P} / \mathrm{AI}$ after either protocol using either the d-32 or -60 pregnancy diagnosis. Consistent with previous studies, $\mathrm{P} / \mathrm{AI}$ was reduced for cows that ovulated smaller follicles in both protocols. A particularly intriguing finding was that smaller follicles were associated with a greatly increased pregnancy loss from d 32 to 60 for cows in the 5-d Cosynch protocol, but not for cows receiving the E2/P4 protocol (Figure 3). This may be one of the most important results from this research trial and may hold the key to understanding some aspects of pregnancy loss during TAI protocol in dairy cattle.

It seems likely that the reduced pregnancy loss from $d$ 32 to 60 in cows receiving the $\mathrm{E} 2 / \mathrm{P} 4$ protocol is related to the use of ECP to synchronize ovulation. A previous study that compared an Ovsynch-type protocol with an E2-based protocol (Vasconcelos et al., 2011b) found no difference between the protocols, but this may be related to the use of ECP to synchronize ovulation at the end of both protocols, rather than $\mathrm{GnRH}$ as used in this study. Thus, increased circulating E2 near AI may produce changes that reduce pregnancy loss from d 32 to 60 after AI. Another intriguing observation in our study that may relate to this idea is that cows that ovulate to $\mathrm{GnRH}$ injection at CIDR insertion in the 5-d Cosynch protocol tended to have greater pregnancy losses $(25.7 \%)$ than cows that did not ovulate to the GnRH injection at CIDR insertion (12.7\%). Other studies that evaluated Ovsynch-type protocols with or without E2 supplementation also had numerical trends toward a reduction in pregnancy losses when E2 was 
incorporated into the protocol: Ovsynch $+\mathrm{E} 2=8.4 \%$ (143) versus Ovsynch $=11.6 \%$ (121) (Souza et al., 2011); Ovsynch + E2 $=7.8 \%$ (204) versus Ovsynch $=9.6 \%$ (178) (Souza et al., 2007); Cosynch $48+\mathrm{E} 2$ $=4.4 \%$ (114) versus Cosynch $=485.0 \%$ (100) versus Cosynch $72+\mathrm{ECP}=1.9 \%(105)$ versus Cosynch $=$ $2.7 \%$ (111) (Hillegass et al., 2008). Also consistent with this concept, Galvão et al. (2004) reported that cows detected in estrus had lower pregnancy loss [estrus = $16.1 \%(224)$ no estrus $=29.6 \%(27)]$. In the present study, we also found a numerical trend toward greater pregnancy loss in cows that did not show estrus (19.7 vs.12.4\%). Perry et al. (2005) reported that GnRHinduced ovulation of small follicles $(<11.3 \mathrm{~mm})$ in beef cows was associated with decreased pregnancy rates and deceased circulating concentrations of E2 at AI and greater pregnancy loss, although pregnancy outcome following spontaneous estrus and ovulation was not affected by follicle diameter. All of these data are consistent with the concept that greater circulating E2 near AI may reduce pregnancy loss at the later embryonic stages (32 to $60 \mathrm{~d}$ after AI). Clearly, this concept will require more direct testing in future trials.

One unexpected result that we encountered during analysis of these experimental data was that heat stress had a differential effect on $\mathrm{P} / \mathrm{AI}$ in cows bred to $\mathrm{GnRH}$ versus E2/P4 protocols (Table 3). It is well established that heat stress can reduce $\mathrm{P} / \mathrm{AI}$ in lactating cows (Vasconcelos et al., 2006, 2011a,b,c). We anticipated that it might be difficult to detect any differences between these 2 protocols in the present experiment due to the low P/AI that was anticipated during heat stress. Contrary to this idea, we may have only been able to detect differences between these protocols because this experiment was performed during heat stress, because not even trends for effects of the protocols were detected in cows with an absence or minor heat stress during the protocol. This intriguing result should be directly tested in future experiments. One potential reason for this observation may be that plasma E2 concentrations are reduced by heat stress in dairy cows (Wolfenson et al., 1995, 1997; Wilson et al., 1998). The supplementation with E2 may have a positive effect on fertilization, later embryonic development, and subsequent pregnancy maintenance. Cows that had rectal temperatures $\geq 39.1^{\circ} \mathrm{C} 2$ or more times can be attributed to their lower ability of dissipating heat. Vasconcelos et al. (2011a) detected that increased milk production only impaired pregnancy maintenance in recipient dairy cows when associated within an increase in rectal temperatures. Ravagnolo and Misztal (2000) concluded that genetic variation for heat tolerance is important and that selection for milk production and heat tolerance is possible because of the low negative correlation between them.

\section{CONCLUSIONS}

The paradox of this study is that a protocol that apparently produced better estrous cycle synchronization in response to the protocol (5-d Cosynch) did not improve P/AI, and by some measures decreased P/AI of the lactating dairy cows. For example, percentage of cows that had their estrous cycle synchronized was greater for cows treated with the 5-d Cosynch protocol than for cows treated with an E2/P4 protocol. In addition, cows in the 5-d Cosynch protocol had greater concentrations of $\mathrm{P} 4$ and a greater percentage of cows with a $\mathrm{CL}$ at the time of $\mathrm{PGF}_{2 \alpha}$ treatment. However, cows in the $\mathrm{E} 2 / \mathrm{P} 4$ protocol had higher $\mathrm{P} / \mathrm{AI}$ than cows in the 5-d Cosynch protocol at the d-60 pregnancy diagnosis due to greater pregnancy loss in cows treated with the 5-d Cosynch protocol than in cows treated with the E2/P4 protocol. The most obvious potential explanation for these results is that circulating E2 concentrations were greater in the cows that had ovulation induced with ECP rather than GnRH. Although we did not measure circulating E2 in this trial, the physiological effects of elevated E2 concentration are clearly manifest in the greater expression of estrus in the cows in the E2/P4 protocol compared with the 5 -d Cosynch protocol. Thus, we speculate that the improved $\mathrm{P} /$ $\mathrm{AI}$ and reduced pregnancy loss in the cows in the E2based protocol resulted from increased circulating E2 concentrations near the time of TAI, which may have a positive effect on fertilization, later embryonic development, and subsequent pregnancy maintenance.

\section{REFERENCES}

Berman, A., Y. Folman, M. Kaim, M. Mamen, Z. Herz, D. Wolfenson, A. Arieli, and Y. Graber. 1985. Upper critical temperatures and forced ventilation effects for high-yielding dairy cows in a subtropical climate. J. Dairy Sci. 68:1488-1495.

Bisinotto, R. S., E. S. Ribeiro, L. T. Martins, R. S. Marsola, L. F. Greco, M. G. Favoreto, C. A. Risco, W. W. Thatcher, and J. E. Santos. 2010. Effect of interval between induction of ovulation and artificial insemination (AI) and supplemental progesterone for resynchronization on fertility of dairy cows subjected to a 5-d timed AI program. J. Dairy Sci. 93:5798-5808.

Bleach, E. C., R. G. Glencross, and P. G. Knight. 2004. Association between ovarian follicle development and pregnancy rates in dairy cows undergoing spontaneous oestrous cycles. Reproduction 127:621-629.

Bridges, G. A., L. A. Helser, D. E. Grum, M. L. Mussard, C. L. Gasser, and M. L. Day. 2008. Decreasing the interval between GnRH and $\mathrm{PGF}_{2 \alpha}$ from 7 to 5 days and lengthening proestrus increases timedAI pregnancy rates in beef cows. Theriogenology 69:843-851.

Cerri, R. L., H. M. Rutigliano, R. C. Chebel, and J. E. Santos. 2009. Period of dominance of the ovulatory follicle influences embryo quality in lactating dairy cows. Reproduction 137:813-823.

Cerri, R. L., J. E. Santos, S. O. Juchem, K. N. Galvão, and R. C. Chebel. 2004. Timed artificial insemination with estradiol cypionate or insemination at estrus in high-producing dairy cows. J. Dairy Sci. 87:3704-3715.

Chebel, R. C., J. E. Santos, R. L. Cerri, H. M. Rutigliano, and R. G. Bruno. 2006. Reproduction in dairy cows following progester- 
one insert presynchronization and resynchronization protocols. J. Dairy Sci. 89:4205-4219.

Demetrio, D. G., R. M. Santos, C. G. Demetrio, and J. L. M. Vasconcelos. 2007. Factors affecting conception rates following artificial insemination or embryo transfer in lactating Holstein cows. J. Dairy Sci. 90:5073-5082.

FASS (Federation of Animal Science Societies). 1999. Guide for the Care and Use of Agricultural Animals in Agricultural Research and Teaching. No. 1. FASS, Savoy, IL.

Galvão, K. N., J. E. P. Santos, S. O. Juchem, R. L. Cerri, A. C. Coscioni, and M. Villaseñor. 2004. Effect of addition of a progesterone intravaginal insert to a timed insemination protocol using estradiol cypionate on ovulation rate, pregnancy rate, and late embryonic loss in lactating dairy cows. J. Anim. Sci. 82:3508-3517.

Giordano, J. O., M. C. Wiltbank, J. N. Guenther, R. Pawlisch, S. Bas, A. P. Cunha, and P. M. Fricke. 2012. Increased fertility in lactating dairy cows resynchronized with Double-Ovsynch compared with Ovsynch initiated $32 \mathrm{~d}$ after timed artificial insemination. J. Dairy Sci. 95:639-653.

Hillegass, J., F. S. Lima, M. F. Sá Filho, and J. E. P. Santos. 2008. Effect of time of artificial insemination and supplemental estradiol on reproduction of lactating dairy cows. J. Dairy Sci. 91:4226-4237.

Lonergan, P. 2011. Influence of progesterone on oocyte quality and embryo development in cows. Theriogenology 76:1594-1601.

López-Gatius, F., M. López-Béjar, M. Fenech, and R. H. F. Hunter. 2005. Ovulation failure and double ovulation in dairy cattle: Risk factors and effects. Theriogenology 63:1298-1307.

Martins, J. P., R. K. Policelli, and J. R. Pursley. 2011. Luteolytic effects of cloprostenol sodium in lactating dairy cows treated with G6G/Ovsynch. J. Dairy Sci. 94:2806-2814.

NRC. 2001. Nutrient Requirements of Dairy Cattle. No. 7. National Academies Press, Washington, DC.

Pereira, M. H. C., C. P. Sanches, T. G. Guida, A. D. P. Rodrigues, F. L. Aragon, M. B. Veras, P. T. Borges, M. C. Wiltbank, and J. L. M. Vasconcelos. 2013. Timing of prostaglandin $\mathrm{F}_{2 \alpha}$ treatment in an estrogen-based ovulation synchronization protocol for timed artificial insemination or embryo transfer in lactating dairy cows. J. Dairy Sci. 96:2837-2846.

Perry, G. A., M. F. Smith, M. C. Lucy, J. A. Green, T. E. Parks, M. D. MacNeil, A. J. Roberts, and T. W. Geary. 2005. Relationship between follicle size at insemination and pregnancy success. Proc. Natl. Acad. Sci. USA 102:5268-5273.

Pursley, J. R., M. R. Kosorok, and M. C. Wiltbank. 1997. Reproductive management of lactating dairy cows using synchronization of ovulation. J. Dairy Sci. 80:301-306.

Pursley, J. R., M. O. Mee, and M. C. Wiltbank. 1995. Synchronization of ovulation in dairy cows using $\mathrm{PGF}_{2 \alpha}$ and $\mathrm{GnRH}$. Theriogenology 44:915-923.

Ravagnolo, O., and I. Misztal. 2000. Genetic component of heat stress in dairy cattle, parameter estimation. J. Dairy Sci. 83:2126-2130.

Ribeiro, E. S., A. P. A. Monteiro, F. S. Lima, H. Ayres, R. S. Bisinotto, M. Favoreto, L. F. Greco, R. S. Marsola, W. W. Thatcher, and J. E. P. Santos. 2012. Effects of presynchronization and length of proestrus on fertility of grazing dairy cows subjected to a 5-day timed artificial insemination protocol. J. Dairy Sci. 95:2513-2522.

Rutigliano, H. M., F. S. Lima, R. L. Cerri, L. F. Greco, J. M. Vilela, V. Magalhães, F. T. Silvestre, W. W. Thatcher, and J. E. Santos, 2008. Effects of method of presynchronization and source of selenium on uterine health and reproduction in dairy cows. J. Dairy Sci. 91:3323-3336.

Santos, J. E., C. D. Narciso, F. Rivera, W. W. Thatcher, and R. C. Chebel. 2010. Effect of reducing the period of follicle dominance in a timed artificial insemination protocol on reproduction of dairy cows. J. Dairy Sci. 93:2976-2988.

Santos, R. M., and J. L. M. Vasconcelos. 2006. Concentrate intake and plasmatic progesterone concentration in Holstein cows. Arquivo Brasileiro Medicina Veterinaria Zootecnia 58:1162-1167.

Souza, A. H., A. P. Cunha, D. Z. Caraviello, and M. C. Wiltbank. 2005. Profiles of circulating estradiol-17 $\beta$ after different estrogen treatments in lactating dairy cows. Anim. Reprod 2:224-232.
Souza, A. H., A. Gümen, E. P. Silva, A. P. Cunha, J. N. Guenther, C. M. Peto, D. Z. Caraviello, and M. C. Wiltbank. 2007. Supplementation with estradiol-17 $\beta$ before the last gonadotropin-releasing hormone injection of the Ovsynch protocol in lactating dairy cows. J. Dairy Sci. 90:4623-4634.

Souza, A. H., E. P. Silva, A. P. Cunha, A. Gümen, H. Ayres, D. J. Brusveen, J. N. Guenther, and M. C. Wiltbank. 2011. Ultrasonographic evaluation of endometrial thickness near timed AI as a predictor of fertility in high-producing dairy cows. Theriogenology 75:722-733.

Souza, A. H., S. Viechnieski, F. A. Lima, F. F. Silva, R. Araújo, G. A. Bó, M. C. Wiltbank, and P. S. Baruselli. 2009. Effects of equine chorionic gonadotropin and type of ovulatory stimulus in a timedAI protocol on reproductive responses in dairy cows. Theriogenology $72: 10-21$.

Townson, D. H., P. C. W. Tsang, W. R. Butler, M. Frajblat, L. C. Griel Jr., C. J. Johnson, R. A. Milvae, G. M. Niksic, and J. L. Pate. 2002. Relationship of fertility to ovarian follicular waves before breeding in dairy cows. J. Anim. Sci. 80:1053-1058.

Vasconcelos, J. L. M. R. F. Cooke, D. T. G. Jardina, F. L. Aragon, M. B. Veras, S. Soriano, N. Sobreira, and A. B. Scarpa. 2011a. Associations among milk production and rectal temperature on pregnancy maintenance in lactating recipient dairy cows. Anim. Reprod. Sci. 127:140-147.

Vasconcelos, J. L. M., D. G. Demétrio, R. M. Santos, J. R. Chiari, C A. Rodrigues, and O. G. Sá Filho. 2006. Factors potentially affecting fertility of lactating dairy cow recipients. Theriogenology $65: 192-200$

Vasconcelos, J. L. M., D. T. Jardina, O. G. Sá Filho, F. L. Aragon, and M. B. Veras. 2011b. Comparison of progesterone-based protocols with gonadotropin-releasing hormone or estradiol benzoate for timed artificial insemination or embryo transfer in lactating dairy cows. Theriogenology 75:1153-1160.

Vasconcelos, J. L. M., O. G. Sá Filho, P. L. Justolin, P. Morelli, F. L. Aragon, M. B. Veras, and S. Soriano. 2011c. Effects of postbreeding gonadotropin treatments on conception rates of lactating dairy cows subjected to timed artificial insemination or embryo transfer in a tropical environment. J. Dairy Sci. 94:223-234.

Vasconcelos, J. L. M., R. Sartori, H. N. Oliveira, J. G. Guenther, and M. C. Wiltbank. 2001. Reduction in size of the ovulatory follicle reduces subsequent luteal size and pregnancy rate. Theriogenology $56: 307-314$.

Vasconcelos, J. L. M., R. W. Silcox, G. J. Rosa, J. R. Pursley, and M. C. Wiltbank. 1999. Synchronization rate, size of the ovulatory follicle, and pregnancy rate after synchronization of ovulation beginning on different days of the estrous cycle in lactating dairy cows. Theriogenology 52:1067-1078.

West, J. W. 2003. Effects of heat-stress on production in dairy cattle. J. Dairy Sci. 86:2131-2144.

Wildman, E. E., P. E. W. G. M. Jones, R. L. Boman, H. F. Troutt Jr., and T. N. Lesch. 1982. A dairy cow body condition scoring system and its relationship to selected production characteristics. J. Dairy Sci. 65:495-501.

Wilson, S. J., C. J. Kirby, A. T. Koenigsfeld, D. H. Keisler, and M. C. Lucy. 1998. Effects of controlled heat stress on ovarian function of dairy cattle. 2. Heifers. J. Dairy Sci. 81:2132-2138.

Wiltbank, M. C., R. Sartori, M. M. Herlihy, J. L. M. Vasconcelos, A B. Nascimento, A. H. Souza, H. Ayres, A. P. Cunha, A. Keskin, J. N. Guenther, and A. Gumen. 2011. Managing the dominant follicle in lactating dairy cows. Theriogenology 76:1568-1582.

Wolfenson, D., B. J. Lew, W. W. Thatcher, Y. Graber, and R. Meidan. 1997. Seasonal and acute heat stress effects on steroid production by dominant follicles in cows. Anim. Reprod. Sci. 47:9-19.

Wolfenson, D., W. W. Thatcher, L. Badinga, J. D. Savio, R. Meidan, B. J. Lew, R. Braw-Tal, and A. Berman. 1995. Effect of heat stress on follicular development during the estrous cycle in lactating dairy cattle. Biol. Reprod. 52:1106-1113. 